\title{
FEEDING SQUIRRELS
}

\author{
Paul Brownsey
}

When I was young, one of my favourite devices for inviting the approbation of adults was to tell my story of the Funny lady who had snatched my bag of squirrel nuts. As young as sixteen I had replaced 'my bag' by the sophisticated objectivity of 'a young boy's bag'.

It took fifty years to discover that she was not Funny.

My story grew out of an incident in September, 1949. I had suffered a severe bout of asthma, and Dr Gricr suggested a change of air for me. I do not know whether she really thought a change of air would itself make a difference - after all, we lived in a Dumfriesshire village where good fresh air abounded. She may have been effecting the parentectomy which, I have been told, sometimes helps asthmatic children. Money was found for the train journey, and I made it alone, though I was only eight. I was instructed, without explanation, to make surc I was always in a compartment with ladies in it, but it did not occur to me that anything needed explaining. I was not nervous, being elevated and safeguarded by the 
anxicty with which my parents placed me on board and with which, many hours later, Uncle Joseph and Auntic Gina met me at Pen Mill station on the outskirts of Yeovil in Somerset. As we walked up from the station to their house, passing a hotel (I had never been in a hotel and pcople who stayed in hotels were to me as mysterious as negroes), Uncle Joseph joked and laughed, confirming that he belonged to the category of kind uncles, not wicked ones. Auntie Gina told me the weather had been lovely, and her benign Somerset drawl secmed an unconditional promise that it would continue so.

I was shocked in my twenties to overhear her tell her daughter-in-law in that same benign drawl, "If I never bloody see you again, that'll be too soon for me.'

Officially, I was 'still weak' from my illness, but this was an article of faith not easy to reconcile with the energy and happiness with which I roamed the quiet roads, where the houses contained only happy families, nothing odd or Funny. At one point you could cut up through the houses to a grassy knoll walked by nice people with their dogs, and on its other side was a small wood. I was a bookish child, which pcople said was a good thing seeing as I was off school so much with my illnesses, and they would observe, smilingly, that I never went anywhere without a book. When I came across a seat in the wood - it was just a rotting plank anciently nailed to two stumpy uprights and was damp-looking, so that I ought to have remembered the likely consequences for my chest - I sat down to read in the quiet autumn sunshine.

I was startled, then pierced by delight, as a grey squirrel darted onto the seat, come to see me. Oh, there was a natural ache in its sleek fur to be fondled. I reached out a hand. It retreated but soon approached again, secretly intimating to me that its caution was only pretend caution and that it was just waiting for the moment when the rules allowed it to give itself to be stroked by me. This time, wise, I kept my reached-out hand still, and tickling delicate teeth courteously tested a nut-like fingertip beforc their possessor leapt manically from the bench. 
'Ooh yes, they're tame there.' Auntic Gina's tone of voice initiated me into something that all sensible people knew. 'People go and feed them, Sunday afternoons.' And it became my habit, in the solitude of fine weekday afternoons, to set off for what I came to call Squirrel Wood, equipped with my book, shelled peanuts in a paper bag for the squirrels, and a slice of Auntic Gina's seedcake (for, being ill, I was to be built up).

In my story I liked to emphasise the picture of a young boy sitting all alone in the landscape, holding out a nut though not a squirrel was to be seen, and calling, 'Squirrels! Squirrels! Come on, Fluffytail!' Suddenly I realised I was not alone. From deeper in the wood a woman had appeared (though in those days I should have said 'a lady'), bespectacled, walking rapidly, seeming to me to be very tall.

There was purpose and authority about her and I lowered my head, for I feared she had tracked me down to question me about why I was not at school. But I soon realised that that was silly, for my absence was unimpeachably sanctioned, and my fear transformed itself into a not unpleasant expectation that the lady would swoop down on me with an eager expression on her face, as, in my experience, ladies were wont to do. Disappointment caused me to look up. She had halted in the path but she ignored me, surveying a vista of sunpenetrated trees in which leaves sometimes fell surreptitiously and windlessly. Her skirt and coat did not compose what my mother called a costume. Her feet and ankles were snuggled in what I had recently learned to call bootees, fur-trimmed, incongruous with the strong, clegant calves of her brown-stockinged legs.

A very well-mannered child, I said, 'Hello.'

She seemed to notice me for the first time. "What are you doing?'

'Feeding squirrels.'

'You are holding out a nut, intending that a squirrel shall come and take it.'

I nodded delightedly, flattered by the correction, for not every child could have been expected to see the 
distinction. She sat down and shut her eyes, even though the sun was behind us.

I ventured, 'If you wait, they'll come.' I wondered if she would remark on my Scottish accent, which English people usually found charming.

It was as if she had wakened rather than merely opened her' eyes. 'Who will come?'

I told her, 'Squirrels,' and she said, 'Oh, squirrels.'

And then one did show itself, approaching through the trees with stealth that was needless, for I loved the squirrels. I leaned forward with the nut, luring the little thing onward. It circled-it was at my fingers-it bit on the nut while I held tight to it-it reached up its little paws and pressed down on my fingers so that its jaws could get a better purchase on the nut--it tugged the nut free and skittered away with it and I, having had my money's worth, reached for another nut.

The lady was eyeing me distantly: I missed the smiling approval I was accustomed to receive from ladies in our village. Politely I held out a nut to her. 'Would you like to try with a nut? Sometimes you can actually get them to sit on you.'

She took it, looked at it, then threw it in a long are, so that a second squirrel, slinking towards our seat, had no more to do to earn it than digress a yard to its left.

As though she had not had a visible demonstration of the fact, I said, 'They'll actually take from you,' and handed her another nut. This, too, she threw.

'They won't hurt you. Really.'

She said, "Are you going to read your book to the squirrels?'

That brushed, ever so lightly, like a squirrel's tail, against my well-developed sense of the Funny, but all I said was, 'They wouldn't understand.'

'And what is the book?' She spoke as though carrying a book were a perfectly normal thing to do: I was cheated of the wide-eyed awe and encouragement with which ladies usually learned of my bookishness.

'Myths and Legends of Greece and Rome.' To make sure of my tribute I added truthfully, 'I'm reading it for 
the third time.' Old Miss Reith had given it to me, saying in the voice it distressed me to hear my mother mock as posh that it had been her brother's, who had been 'killed in the Great War when he was little more than twice your age. There now!' Dutifully I pictured myself as a soldier, wrapping a thick scarf about me because of my chest.

I laid out still more that the lady in the wood could not fail to think well of. "I like it when Achilles comes back to the war and kills Hector because he has killed his friend Patroclus.' I pronounced it "Patroclus", as if it were a variant of "Patrick".

'Patroclus.' Her amendment of my pronunciation disturbed me, for her emphasis recalled 'Patricia', a girl's name, and I pictured some tight-mouthed silly full of secrets she must not tell me, like Pat Cheve at school.

The lady added, 'Achilles loved Patroclus.'

'But Patro-Patroclus wasn't a lady!'

Then I excluded her from my attention, for a squirrel was at my feet and I waved a nut gently above my knee, saying, 'Come on. You've got to sit on my knee for this one.' Success! It clambered up my long gartered grey sock and, having prised the nut from my fingers, turned its back and sat up, rotating the nut in its little paws with heart-stopping efficiency and grace as it gnawed, its long back feet delicate and cool on my bare knee.

Clump!-a second squirrel leapt from above onto my shoulder and I was self-controlled enough to avoid all swift scaring movement. Slowly I reached up a nut which it strained down from my shoulder to get, resting a supporting paw on the knuckle of my thumb. Beneath my delight I may have been disappointed that all squirrel feet felt the same.

'Nevertheless,' she said, 'Achilles loved Patroclus.'

The translucent veils of common sense swept protectively around me and through them there could be no doubt that I was in the presence of someone who was Funny.

But I struggled to deflect that verdict from her, for I was gallant towards ladies. One of my dreads was that of being made to go to Sunday-school; what went on there 
was another of frizzy-haired Pat Cheve's secrets. Though my parents, unaccountably, had not yet raised the question of my going, still this did not protect me from the visits the minister paid to ordinary school, his eye upon me as someone to be reported to the authorities for not attending Sunday-school. He told us that Jesus said we were to love people, but, I gathered, without the kissing that men did to ladies in the films I was taken to see. I surmised that when the lady said Achilles loved Patroclus, she meant this non-kissing love.

But it was a question, whether Homer, who made up the story of Achilles, could have known about that sort of love, for he lived before Jesus. And anyway, even if the lady did mean that sort of love, she didn't come well out of the situation because in that case she must be Religious, and $1 \mathrm{kncw}$ that being Religious, bringing up religion in ordinary life, was only a specific form of being Funny.

I was hunching in ccstasy: a third squirrel had attached itself to me, clinging to my back. The one on my knee still had its back to me, and I reached out and gently stroked its tail, fine as smoke. But the eye I could see was like a glass marble, ungrateful, unchanging, without recognition of me as a nice person. Was there stupidity there?-I remembered how they could not tell nuts from fingertips, without testing them with their teeth.

'The death of Patroclus: what was it?' After a period of silence the lady was speaking again. 'Perhaps it was only the loss to Achilles when Achilles gave up anxious love, spoil-sport love, predatory love.'

It was some years before I worked out what that last adjective had been.

I gave my attention to the squirrel whose tail I stroked. Oh! there was a flaw in the wonderful smoothness of its fur, a small V-shaped wound in its back, something dark congealed in it. The thought formed itself (but quickly went away again) that when the squirrels were 'chasing each other' through the treetops it might not be the friendly game it gave me such pleasure to watch. 
The lady stood up and the squirrel on my knee leapt away. Without a word she reached into my lap; my remaining squirrels jumped ship. Oh, she had taken my paper bag of nuts! And then a strong swift stroke of her arm scattered them distantly, irretrievably.

'Give them!' she cried. 'Give them freely!'

She extracted the few remaining nuts, flung them after the rest, screwed up the bag, dropped it, strode away. As I watched her out of sight, I unwrapped Auntie Gina's seedcake from its grease-proof bag and ate it.

'My, there's some Funny people about,' Auntie Gina said complacently when I got home. She told Uncle Joseph, just then coming in from his work in a builder's office, 'He was up in Squirrel Wood and a Funny woman took his nuts and threw them all on the ground.' Since the woman was Funny, no other explanation of her conduct was needed or even possible. In a chuckling way that did not quite exclude indignation, Uncle Joseph said, 'There's no-one lives around here like that,' and, indeed, she did not appear again when I visited Squirrel Wood, though I half-hoped she would.

And then, forty years later, on a lazy Sunday morning, a newsprint photograph suddenly presented me with the face I remembered. My eyes noticed it only because it was so obviously a snapshot blown up, testimony to a lost private moment in which the subject, whoever she was, had adopted a delicate, fingers-to-the-cheek pose that did not for a moment diminish the remorseless intelligence of her gaze. I let out a yell of recognition which caused Patrick to frown, for he dislikes in me what he regards as attention-seeking propensities.

'It's her!' I cried, when he failed to ask why I had yclled. 'The Funny lady. You know, grabbed my nuts - '

'The first of many.'

Undeterred I took the newspaper across to him, kneeling to show him the face full of knowledge with its scholar's glasses and hair styled short and high.

'Who knows?' was all he said, his glance already returned to his section of the newspaper. 
This lack of response did not seriously trouble me, for he was unemployed following privatisation of the part of the civil service in which he had worked, and so he had no option, at least for the time being, but to continue to live with me.

On my knees I relayed information to him. The photograph, printed to accompany a biography of her, was of the novelist and poet, Sylvia Townsend Warner. For the greater part of her life she loved an immensely difficult woman named Valentine Ackland, who went in for self-scrutiny and self-dramatising crises and selfconscious sincerity. Valentine had not scrupled to engage in a supplementary love-affair with another woman, from America. To test the possibilities of this other relationship she brought the American to stay with her in the home she shared with Sylvia. The terrible pain she caused Sylvia was subservient to the anguished satisfaction of attributing to herself the virtues of openness, honesty, integrity of feeling, etc. Nobly, Sylvia moved out for the time being to the meek waiting solitude of a hotel room so that the dreadful Valentine might have the fullest scope for trying, in Sylvia's own home, whether she preferred to spurn and desert Sylvia for the other.

That had been in September, 1949. The reviewer had named the hotel, perhaps because the banal detail gave poignancy: The Pen Mill Hotel, Yeovil. So as Auntic Gina and Uncle Joseph and I, still enveloped in the lovely trainsmoke reek which I had been told was bad for me to breathe, walked up past the hotel, poor Sylvia, very likely, had been within, crouching-so I now pictured herbefore a single electric bar in a dismal room, wondering how to fill the wecks of agonising waiting without weakening in her astounding generosity.

And Sylvia was a writer, prolific, acclaimed! That, after all, was why they had produced a biography of her. I had recently joined a writers' group in the bungalowed suburb in which Patrick and I live, for I was keen to find an audience for some poems I had written, and one thing I had learned was that wisdom flows through writers, at least good ones, whether or not you can detect it in the 
living person who writes. It was necessary to revise my life-narrative. The woman who scattered my squirrel nuts had not been Funny. She was no longer to be cast alongside the client in a divorce case who said she knew God had appointed me to represent her and who told me, when I laid out the options and asked for her instructions, to pray to God for an answer. Nor was she comparable to the man in a Colorado muscum in 1969 who urged me to write to the Duke of Edinburgh to enlist his authority so that the world might be saved from the floods that the incoming Age of Aquarius would unleash. Sylvia had been a sybil. I had touched the hem of her garment-for I think the edge of her brownish tweed skirt did touch my knce, bare below short trousers, as we sat on the little seat in Squirrel Wood-and so I had had privileged contact with mysteries that could transform the world and even my life. 
Copyrighted image removed

St Nicholas Church, Chaldon Herring, Dorset.

Sylvia Townsend Warner and Valentine Ackland are interred in the churchyard of St Nicholas. 